\title{
Phosphorus Uptake and Growth of Wild-Type Barley and Its Root-Hairless Mutant Cultured in Buffered-and Non-Buffered-P Solutions
}

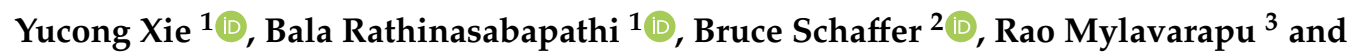 \\ Guodong Liu 1,*(D) \\ 1 Horticultural Sciences Department, University of Florida, 1253 Fifield Hall, Gainesville, FL 32611, USA; \\ leslieyx@colostate.edu (Y.X.); brath@ufl.edu (B.R.) \\ 2 Tropical Research and Education Center, University of Florida, 18905 S.W. 280th Street, \\ Homestead, FL 33031, USA; bas56@ufl.edu \\ 3 Soil and Water Sciences Department, University of Florida, 2181 McCarty Hall, Gainesville, FL 32611, USA; \\ raom@ufl.edu \\ * Correspondence: guodong@ufl.edu; Tel.: +1-352-273-4814
}

Received: 7 September 2020; Accepted: 7 October 2020; Published: 13 October 2020

\begin{abstract}
Root hairs play an important role in phosphorus (P) nutrition of plants. To better understand the relationship between root hairs and $\mathrm{P}$ acquisition efficiency (PAE) in barley, experiments were conducted with the wild-type barley (cv. 'Pallas') and its root-hairless mutant (brb). A hydroponic split-root system was used to supply $\mathrm{P}$ as $\mathrm{Ca}_{3}\left(\mathrm{PO}_{4}\right)_{2}$ (tri-calcium phosphate, TCP) to one-half and other nutrients to the other half of the root system. Using TCP as a sole P source can simulate a soil solution with buffered low P concentration in hydroponics to induce prolific root hair growth. Root morphology, plant growth, and P uptake efficiency were measured with $50 \mathrm{mg} \mathrm{L}^{-1} \mathrm{TCP}$ supplied to the roots in the split-root system and 0,35 , or $1000 \mu \mathrm{M} \mathrm{NaH}_{2} \mathrm{PO}_{4}$ in a non-split-root hydroponic system. The wild-type plants developed root hairs, but they did not contribute to the significant genotypic differences in the P uptake rate when a soluble P source was supplied in the non-split root system, indicating that root hair formation does not contribute to P uptake in a non-split root solution. On the other hand, when grown in a split-root system with one-half of the roots supplied with TCP, the wild-type showed 1.25-fold greater P uptake than the root hairless mutant. This study provides evidence that root hairs play an essential role in plant $\mathrm{P}$ uptake when $\mathrm{P}$ bioavailability is limited in the root zone.
\end{abstract}

Keywords: Hordeum vulgare L.; split-root system; P uptake; root hair length and density; buffered-P hydroponics

\section{Introduction}

Low phosphorus $(\mathrm{P})$ bioavailability is one of the main constraints to plant growth and fecundity. Due to phosphate interaction with inorganic and organic components in soil, its mobility and accessibility are usually low [1,2]. As a consequence of P immobilization and competition between plants and soil microorganisms, almost $80 \%$ of applied $\mathrm{P}$ fertilizer is fixed in soil; hence, unavailable for plant uptake [3]. In most soil solutions, the concentration of inorganic phosphate (Pi) is less than $10 \mu \mathrm{M}$, which is even lower than the concentrations of some micronutrients in many plants [4]. To ensure high productivity of crop and cropland, large amounts of $\mathrm{P}$ fertilizers are often applied for crop production in many agricultural areas throughout the world. Excessive application of P fertilizer to meet plants' $P$ requirements presents environmental risks, e.g., eutrophication results in algae blooms and threatens the ecosystem [5]. Identifying elite genotypes efficient in P uptake and utilization to 
breed P-efficient varieties is imperative for crop adaption to low-P bioavailability and for agricultural and environmental sustainability.

To calculate crop P efficiency, two terms are widely used, including P acquisition efficiency (PAE), which is also referred to as P uptake efficiency, and P utilization efficiency (PUE) [6-8]. PAE is defined as plant $P$ uptake per bioavailable $P$ in soil, while the PUE is calculated as the grain yield per unit of acquired $\mathrm{P}$ [9]. In sufficient-P conditions, PUE contributes the most to enhanced plant $\mathrm{P}$ efficiency. In contrast, in low-P conditions, PAE contributes twice as much to enhanced P-use efficiency than that of PUE [8,9].

In low-P conditions, plants have evolved several adaptations in root morphological characteristics to enhance PAE [8]. One of these adaptations is to increase the number and length of root hairs, which was reported to be the most efficient strategy to deal with external P limitation and can contribute up to $90 \%$ of $P$ acquisition by plants $[10,11]$. Compared with other root hair traits such as root hair length, root hair density has the least effect on PAE due to competition of space among root hairs [12]. Conversely, root hair length increases significantly in P-limited conditions, and thus is the morphological trait efficient for enhancing P uptake [12]. Most studies of the correlation between root hair growth and PAE have been conducted in low-P soil. However, roots can be damaged during sampling, especially while removing soil particles from the roots. Compared with traditional soil culture, growing plants hydroponically allows relatively easy measurement of root hair growth without interference from the growth medium. Hydroponic solutions with tricalcium phosphate (TCP) as the only P source can mimic a soil solution with a buffered low-P concentration, in cases in which no other ions co-exist with TCP [13]. It has been reported in wheat that plant tissue P accumulation was significantly greater when TCP was supplied with the other nutrients than when it was provided separately from the other nutrients in a split-root system [13]. This finding can be explained by the inequality in the uptake of cations and anions from the nutrient solution, which further changed the solution $\mathrm{pH}$, and hence $\mathrm{P}$ bioavailability. Therefore, a split-root system can sustain the low $\mathrm{P}$ signal to the plant on one side of the root system with TCP and supply the other nutrients to the plant on the other side of the system. This application of TCP to roots in a split-root system is important because a low-P concentration in the soil solution induces prolific root hair growth with the other nutrients not being the limiting factor [13].

A barley mutant $(b r b)$ was discovered, which completely lacks the ability to form root hairs regardless of growth medium or P bioavailability. Subsequent genetic and anatomical studies indicated that this root morphological trait was the consequence of a single recessive gene mutation from the wild-type cv. 'Pallas', which has normal root hairs [14-16]. This single gene regulating root hair formation and elongation in barley was isolated and identified as $\beta$-expansin (HvEXPB1) [17]. Studies conducted on this root hairless mutant suggest that root hairs are essential in $\mathrm{P}$ acquisition and plant survival under limited P soil conditions, whereas root hairs are dispensable under high P soil conditions. On the contrary, the absence of root hairs in solution culture does not significantly affect plant phenotypic characteristics $[14,16]$. Those findings facilitated the transition of a root hair studies from the model plant, Arabidopsis, to agronomically important monocots including barley [15]. The comparison between the brb barley mutant and its genetic parent 'Pallas' [15] can be useful for determining the role of root hairs in $\mathrm{P}$ uptake and plant growth in various $\mathrm{P}$ bioavailability conditions.

The objectives of this study were to (i) compare the effects of scarcely soluble phosphate and soluble phosphate on root hair development and plant growth and (ii) quantify the effects of root hairs on P uptake efficiency and plant growth. To accomplish the first objective, we conducted a series of split-root and non-split root experiments with different concentrations of P supplied to the roots. To achieve the second objective, we used a root hairless barley mutant ( $b r b)$ and its corresponding genetic wild type ('Pallas') and compared P uptake and plant growth between the two genotypes 


\section{Materials and Methods}

\subsection{Plant Materials and Growth Conditions}

Barley seeds of the wild-type (WT-'Pallas', a spring barley cultivar) and a root-hairless mutant (MT-bald root barley, brb; with root morphological and anatomical analyses confirming its root hair deficiency) were obtained from T. S. Gahoonia at the Plant Nutrition and Soil Fertility Laboratory, Department of Agricultural Sciences, Royal Veterinary and Agricultural University, Copenhagen, Denmark [15].

Experiments were conducted in a greenhouse in Gainesville $\left(29^{\circ} 38^{\prime} 53.99^{\prime \prime} \mathrm{N}-82^{\circ} 20^{\prime} 57.98^{\prime \prime} \mathrm{W}\right)$, FL, USA. Seeds of the two genotypes were soaked in distilled water, kept in the dark for $12 \mathrm{~h}$ and then germinated. The germination rate was measured, and germinated seeds were transferred to new Petri dishes (9-cm diameter) to provide enough space for root growth. The germinated seeds were kept in a growth chamber at $31^{\circ} \mathrm{C}$ for $2-3$ days until the root length reached $5 \mathrm{~cm}$ and then transferred to the greenhouse. The average temperature in the greenhouse was $33^{\circ} \mathrm{C}$, the relative humidity was $75.3 \%$, and the daily light/dark period was $13 / 11 \mathrm{~h}$. Seedlings were kept in an aeroponic (mist culture) system for one day to adapt them to the greenhouse environment, then transplanted into a hydroponic solution with a split-root or non-split-root system. Roots in the aeroponic system were fertilized with a Hoagland nutrient solution containing: $1 \mathrm{mM} \mathrm{KNO}_{3}, 0.25 \mathrm{mM} \mathrm{MgSO}_{4}, 0.25 \mathrm{mM}$ $\mathrm{NH}_{4} \mathrm{H}_{2} \mathrm{PO}_{4}, 1 \mathrm{mM} \mathrm{Ca}\left(\mathrm{NO}_{3}\right) 2 \cdot \mathrm{H}_{2} \mathrm{O}, 0.25 \mathrm{mM}$ Fe-EDDHA, $5 \mu \mathrm{M} \mathrm{CuSO}_{4} \cdot 5 \mathrm{H}_{2} \mathrm{O}, 12.5 \mu \mathrm{M} \mathrm{ZnSO} \cdot 7 \mathrm{H}_{2} \mathrm{O}$, $2.5 \mu \mathrm{M} \mathrm{Na}_{2} \mathrm{MoO}_{4} \cdot 2 \mathrm{H}_{2} \mathrm{O}, 125 \mu \mathrm{M} \mathrm{MnCl}_{2} \cdot 4 \mathrm{H}_{2} \mathrm{O}$; and $125 \mu \mathrm{M} \mathrm{H}_{3} \mathrm{BO}_{3}$. The solution $\mathrm{pH}$ was adjusted to $6.5 \pm 0.2$ by adding $0.1 \mathrm{mM} \mathrm{HCl}$ or $\mathrm{NaOH}$, as needed.

\subsection{Non-Split-Root System}

We first applied a controlled non-split-root system with a no, low, or high $\mathrm{P}$ condition using $\mathrm{NaH}_{2} \mathrm{PO}_{4}$ as soluble P source. There were three treatments (P0, P35, and P1000) and four replications in the non-split-root system, each with a specific $\mathrm{P}$ concentration in the nutrient solution at the beginning and solutions were not changed until harvest. Plants were grown in a 1-L solution with $0 \mu \mathrm{M} \mathrm{NaH}{ }_{2} \mathrm{PO}_{4}$ (P0, no P), $35 \mu \mathrm{M} \mathrm{NaH} \mathrm{PO}_{4}$ (P35, low P), or $1000 \mu \mathrm{M} \mathrm{NaH}_{2} \mathrm{PO}_{4} \mathrm{P}$ (P1000, high P) at the rate of one plant per container. Other nutrients provided were $1 \mathrm{mM} \mathrm{CaCl}_{2}, 1.5 \mathrm{mM} \mathrm{KNO}_{3}, 0.375 \mathrm{mM} \mathrm{NH}_{4} \mathrm{NO}_{3}, 1.75 \mathrm{mM}$ $\mathrm{NaNO}_{3}, 0.25 \mathrm{mM} \mathrm{MgSO}_{4}, 12.5 \mu \mathrm{M} \mathrm{KCl}, 6.25 \mu \mathrm{M} \mathrm{H}_{3} \mathrm{BO}_{3}, 0.5 \mu \mathrm{M} \mathrm{MnSO}_{4} \cdot \mathrm{H}_{2} \mathrm{O}, 0.5 \mu \mathrm{M} \mathrm{ZnSO}{ }_{4} \cdot 7 \mathrm{H}_{2} \mathrm{O}$, $0.125 \mu \mathrm{MCuSO}_{4} \cdot 5 \mathrm{H}_{2} \mathrm{O}, 0.125 \mu \mathrm{M} \mathrm{H}_{2} \mathrm{MoO}_{4}\left(85 \% \mathrm{MoO}_{3}\right)$, and $4.03 \mu \mathrm{M} \mathrm{NaFeDTPA}(10 \% \mathrm{Fe})$. After setting up the system, oxygen was supplied by adding $529 \mu \mathrm{M}$ hydrogen peroxide $\left(\mathrm{H}_{2} \mathrm{O}_{2}\right)$ every other day starting one week after the seedlings were transplanted to hydroponics. The initial $\mathrm{pH}$ of the solution was adjusted to $7.2 \pm 0.2$ by adding $0.1 \mathrm{mM} \mathrm{HCl}$ or $\mathrm{NaOH}$, as needed.

\subsection{Split-Root System}

In the split-root system, we place the two varieties grown with five treatments (TR1-TR5) with four replicates listed in Table 1. In TR1 (TCP/CNS-P), TCP was supplied to one half of the roots, while the Hoagland solution with all other nutrients mentioned above except soluble $\mathrm{P}$ were added to the other half of the roots; in TR2 $\left(\mathrm{H}_{2} \mathrm{O} / \mathrm{CNS}\right)$ distilled water with $4 \mathrm{mM} \mathrm{CaCl}_{2}$ was in one half while complete nutrients with $1 \mathrm{mM} \mathrm{NaH}_{2} \mathrm{PO}_{4}$ was in the other half of roots; in TR3 $\left(\mathrm{H}_{2} \mathrm{O} / \mathrm{CNS}-\mathrm{P}\right)$, left cup was the same as TR2 whereas the right cup contained complete nutrients without $\mathrm{P}$; TR4 $\left(\mathrm{H}_{2} \mathrm{O} / \mathrm{CNS}-\mathrm{P}+\mathrm{TCP}\right)$ contained TCP and other nutrients to one half and distilled water with $4 \mathrm{mM} \mathrm{CaCl}_{2}$ to the other half; TR5 (CNS/CNS) had complete nutrients together with soluble $\mathrm{P}$ added to both halves of the roots as the control. In total, eighty plastic cups with 2 varieties $\times 5$ treatments $\times 4$ replicates $\times 2$ root halves, each with a total volume of $1000 \mathrm{~mL}$, were assembled in forty pairs. The cups in each pair were kept $5 \mathrm{~mm}$ apart to avoid any cross-contamination of nutrients. Twenty uniform and healthy seedlings of each genotype were selected, primary roots were divided into approximately two equal parts with each half placed into one of the paired cups. A foam board (width $=14 \mathrm{~cm}$, length $=28 \mathrm{~cm}$ and thickness $=1.2 \mathrm{~cm}$ ) and black cloning collars (round sponge, $4 \mathrm{~cm}$ in diameter) were used to 
stabilize the seedlings and to cover the opening of the cups as described by Liu et al. [13]. On one side, a modified Hoagland solution without $\mathrm{P}$ (CNS-P) was supplied to the roots as mentioned above. The $\mathrm{NO}_{3}{ }^{-} / \mathrm{NH}_{4}{ }^{+}$ratio in this modified nutrient solution was elevated and maintained at 10.67 to keep the solution $\mathrm{pH}$ stable. Different $\mathrm{P}$ sources supplied included either $31 \mathrm{mg} \mathrm{P} / \mathrm{L}$ by $\mathrm{NaH}_{2} \mathrm{PO}_{4}$ or $10 \mathrm{mg}$ $\mathrm{P} / \mathrm{L}$ by scarcely soluble TCP $\left[\left(\mathrm{Ca}_{3}\left(\mathrm{PO}_{4}\right)_{2}\right]\right.$. To further decrease the solubility of the TCP source, $4 \mathrm{mM}$ calcium chloride $\left(\mathrm{CaCl}_{2}\right)$ was added.

Table 1. Description of treatments applied to either half of the roots in a split-root system. Left and right halves refer to the sides of an observer facing the system.

\begin{tabular}{ccc}
\hline Treatment & Left Cup Contents (LC) & Right Cup Contents (RC) \\
\hline TR1 & $\mathrm{TCP}^{\mathrm{a}}$ & CNS-P ${ }^{\mathrm{b}}$ \\
TR2 & $\mathrm{H}_{2} \mathrm{O}^{\mathrm{c}}$ & CNS \\
TR3 & $\mathrm{H}_{2} \mathrm{O}$ & CNS-P \\
TR4 & $\mathrm{H}_{2} \mathrm{O}$ & CNS-P + TCP \\
TR5 (control) & $\mathrm{CNS}$ & CNS \\
\hline
\end{tabular}

${ }^{\text {a }} 0.05 \mathrm{~g} / \mathrm{L}$ Tri-calcium phosphate (with $4 \mathrm{mM} \mathrm{CaCl}_{2}$ ). ${ }^{\mathrm{b}}$ Complete nutrient solution without $\mathrm{P} .{ }^{\mathrm{c}}$ Distilled water with $4 \mathrm{mM} \mathrm{CaCl}_{2} .{ }^{\mathrm{d}}$ Complete solution with $1 \mathrm{mM} \mathrm{NaH} 2 \mathrm{PO} 4$ as the P source.

\subsection{Quantification of Root Hair Length and Density}

Ten days after transplanting (DAT) seedlings to the hydroponic solution, root hair length, and density were measured. The roots were placed in a Petri dish filled with distilled water and an optical microscope connected to a digital camera was used to photograph root hairs at $20 \times$ and $40 \times$ magnification. This method was the same as Gahoonia reported [18]. In the photos, root hair length $(\mathrm{mm})$ was defined as the average length of ten randomly selected root hairs in a $1 \mathrm{~mm}$ segment of lateral roots having root hairs. Average root hair density was determined as the number of root hairs in the same $1 \mathrm{~mm}$ segment of lateral root for measurement of root hair length [18-20].

\subsection{Phosphorus Uptake Dynamics}

Plant $\mathrm{P}$ uptake dynamics were measured 18 days after transplanting plants to the hydroponic system. Before transferring plants to a measurement solution containing $0.2 \mathrm{mM} \mathrm{CaCl}_{2}$ and $16.1 \mu \mathrm{M}$ $\mathrm{P}\left(0.5 \mathrm{mg} \mathrm{P} \mathrm{L}^{-1}\right.$ from a $1000 \mathrm{mg} \mathrm{L}^{-1}$ stock solution of $\left.\mathrm{NaH}_{2} \mathrm{PO}_{4}\right)$, the roots were thoroughly washed with distilled water and starved in a nutrient starvation solution without any nutrients but containing merely $0.2 \mathrm{mM} \mathrm{CaCl}_{2}$, and $529 \mu \mathrm{M} \mathrm{H}_{2} \mathrm{O}_{2}$ for two days. One liter of measurement solution was either separated equally into two halves for the split-root system or combined for the non-split-root system. The seedlings were then transferred to the measurement solution separated into two equal halves (split-root system) or not separated (non-split-root system). A $500 \mathrm{~mL}$ measurement solution without plants was used as a parallel control for measuring P depletion of the plants from the solution. For the determination of the $\mathrm{P}$ uptake rate, $1 \mathrm{~mL}$ of measurement solution was collected at $0,2,4,6$, and $8 \mathrm{~h}$ and the $\mathrm{P}$ concentration in the solution was determined with a discrete auto analyzer (AQ2, SEAL Analytical, Hanau, Germany). Plant P uptake rate was defined as the total amount of P depleted from the measurement solution per plant divided by the measurement time (h).

\subsection{Plant Biomass Measurements}

After $\mathrm{P}$ uptake dynamic measurements, the plants were harvested within the 24 days after putting them back to the hydroponic system. At harvest, shoots cut from roots of the left and right root halves (in the split-root system) were carefully separated for measuring the dry weight (biomass), and the $\mathrm{P}$ concentration in the plant tissue. Harvested shoot and root tissues were thoroughly rinsed with distilled water to wash TCP particles and other nutrients off, and dried in an oven at $75^{\circ} \mathrm{C}$ for $72 \mathrm{~h}$. Shoot and root dry weights were measured and the root to shoot ratio were calculated [21]. 


\subsection{Tissue P Concentration Determination}

Dry tissue (150 mg $\pm 5.0 \mathrm{mg}$ ) was ground, digested in $6 \mathrm{M}$ hydrochloric acid $(\mathrm{HCl})$ and diluted to $50 \mathrm{~mL}$ with distilled water [22]. Phosphorus concentration in the digested solution was analyzed with an automated discrete analyzer (AQ2, SEAL Analytical, Hanau, Germany) based on United States Environmental Protection Agency Method 365.1 (USEPA, 1983). The P concentration in plant tissue (dry weight, DW) was calculated using the following equation [23]:

$$
\mathrm{P} \text { concentration }(\mathrm{mg} \mathrm{P} / \mathrm{g} \mathrm{DW})=\frac{P \text { concentration in solution }\left(\frac{m g}{L}\right) \times \operatorname{volumn}(L)}{\text { tissue dry matter }(g)}
$$

\subsection{Statistical Analyses}

Treatments (split-root and non-split-root) were arranged in a completely randomized design with four replicates. Treatment differences for root hair length and density were determined by one-way analysis of variance (ANOVA). Phosphorus uptake dynamics, biomass, and P content in plant tissues were analyzed by two-way ANOVA to test genotype $\times \mathrm{P}$ treatment interactions. Mean differences between the genotypes and among the $\mathrm{P}$ treatments were compared with Tukey's honestly significant difference (HSD) test $(p \leq 0.05)$. All data were analyzed with R-studio software (R Foundation for Statistical Computing 2010, Vienna, Austria).

\section{Results}

\subsection{Non-Split-Root System}

The root hairs of the wild type grew $\sim 2.8$ times longer and $\sim 3.5$ times denser in the P0 and P35 treatments, respectively, than in the P1000 treatment (Table 2). As expected, the brb mutant did not form any root hairs regardless of the P treatment.

Table 2. Growth response of two barley genotypes at three P levels in a non-split-root system.

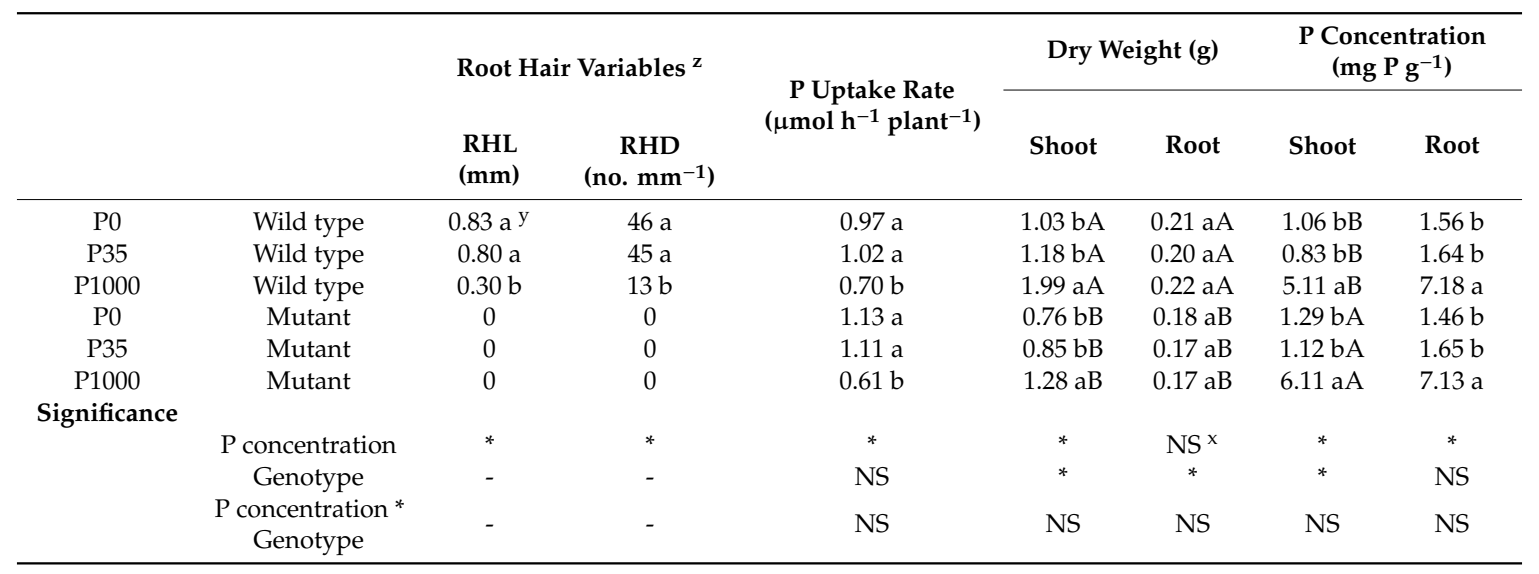

\footnotetext{
${ }^{\mathrm{z}}$ The root hair variables were measured 10 days after transferring (DAT) to the measurement solution. P uptake rate was measured 18 DAT, and biomass and P content in plant tissue were measured in harvested plants 24 DAT. y Different lower-case letters indicate significant difference among different $\mathrm{P}$ concentrations, while different upper-case letters mean statistical difference between the two genotypes $(p \leq 0.05)$ according to a Tukey's HSD test. ${ }^{x}$ NS indicates not significant $(p>0.05)$, and * indicates significant $(p \leq 0.5)$ main effects or interactions according to two-way analysis of variance (ANOVA).
}

No significant $(p>0.05)$ genotypic effect (Figure 1A) or interaction between genotype and $\mathrm{P}$ treatment were observed for the $\mathrm{P}$ uptake rate (Table 2). The $\mathrm{P}$ uptake rate of the wild type was significantly lower in the P1000 treatment $\left(0.7 \mu \mathrm{mol} \mathrm{h}{ }^{-1}\right.$ per plant $)$ than in the P0 $\left(0.97 \mu \mathrm{mol} \mathrm{h}{ }^{-1}\right.$ per plant) or P35 (1.02 $\mu \mathrm{mol} \mathrm{h}^{-1}$ per plant) treatments (Table 2). Similarly, the P uptake rate of seedlings for $b r b$ was significantly lower in the P1000 treatment than in the P0 or P35 treatments (Figure 1A). 

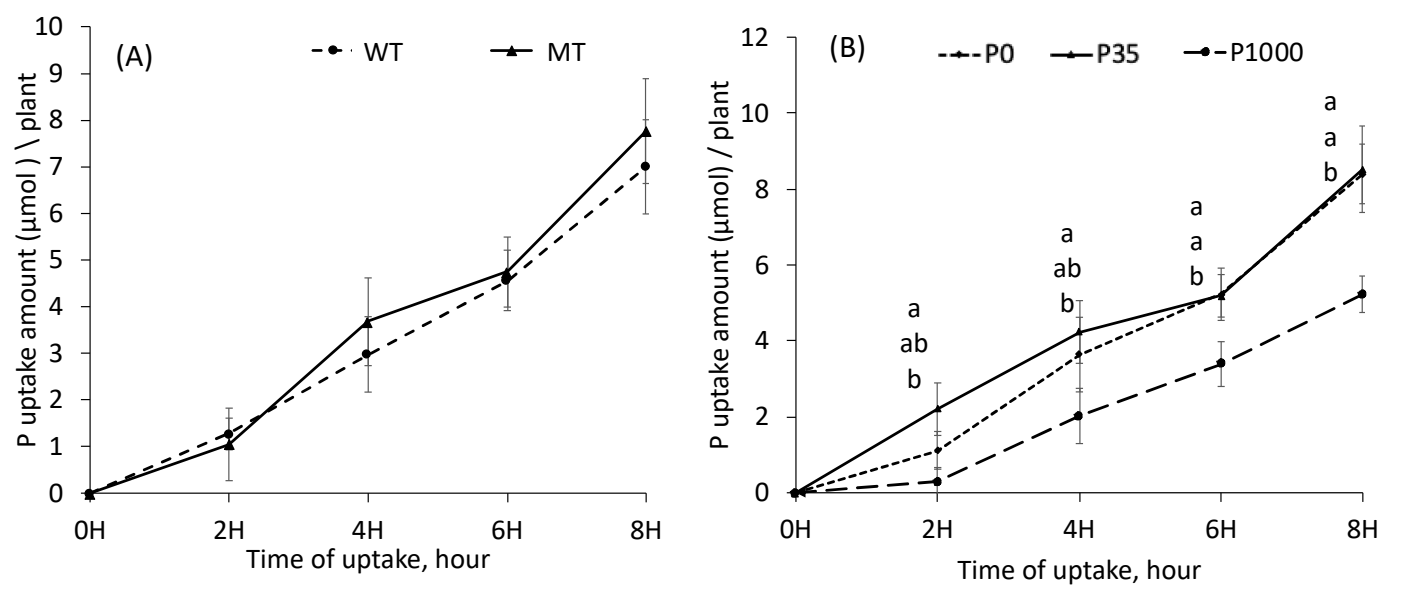

Figure 1. Phosphorus (P) uptake dynamics in two barley genotypes. (A) Comparison of average P uptake of two genotypes, (B) Comparison of average $\mathrm{P}$ uptake under three P levels in the nutrient solution: (1000 (P1000), 35 (P35) or 0 (P0) $\mu \mathrm{M} \mathrm{NaH}_{2} \mathrm{PO}_{4}$ ). Different lower-case letters indicate statistically significant difference $(p<0.05)$ among three $\mathrm{P}$ concentrations. Measurements were made continuously for eight hours. The solution was sampled every two hours to determine the remaining P concentration in the nutrient solution. The bars represent the standard errors of four replicates. WT stands for wild type, and MT for root hairless brb mutant.

After $6 \mathrm{~h}$, seedlings in the P0 and P35 treatments had a total P uptake that was 1.5 times greater than those in the P1000 treatment. After $8 \mathrm{~h}$, seedlings in the P0 and P35 treatments had a total P uptake 1.6 time greater than those in the P1000 treatment (Figure 1B).

There were large genotypic variations in shoot and root biomass in the non-split-root system. For example, the wild type produced 1.5 and 1.8 times more shoot and root biomass than the $b r b$ mutant. For the wild type, the shoot dry weight at 24 DAT was significantly greater in the P1000 treatment (1.99 $\left.\mathrm{g} \mathrm{plant}^{-1}\right)$ than in the P35 (1.18 g plant $\left.{ }^{-1}\right)$ or P0 (1.03 g plant $\left.{ }^{-1}\right)$ treatments. Similarly, the $b r b$ seedlings in the P1000 treatment had significantly greater shoot dry weight $\left(1.28 \mathrm{~g} \mathrm{plant}^{-1}\right)$ than those in the P35 (0.85 $\left.\mathrm{g} \mathrm{plant}^{-1}\right)$ or P0 (0.76 g plant $\left.{ }^{-1}\right)$ treatments (Table 2).

The shoot $\mathrm{P}$ concentration was significantly greater in $b r b$ mutant than in the wild type in all the $\mathrm{P}$ treatments even though the mutant did not form root hairs (Table 2). However, there was no genotypic effect on root $\mathrm{P}$ concentration. Considering the treatment effect on shoot $\mathrm{P}$ concentration, higher external P led to a higher shoot P concentration. For example, the wild type in the P1000 treatment had the highest shoot $\mathrm{P}$ concentration $\left(5.11 \mathrm{mg} \mathrm{P} \mathrm{g}^{-1}\right)$ compared to those in the $\mathrm{P} 0\left(1.06 \mathrm{mg} \mathrm{P} \mathrm{g}^{-1}\right)$ or P35 ( $0.83 \mathrm{mg} \mathrm{P} \mathrm{g}^{-1}$ plant) treatments. The $b r b$ mutant accumulated $6.11 \mathrm{mg} \mathrm{P} \mathrm{g}^{-1}$ in the P1000 treatment, which was significantly higher than that in the P0 $\left(1.29 \mathrm{mg} \mathrm{P} \mathrm{g}^{-1}\right)$ or P35 $\left(1.12 \mathrm{mg} \mathrm{P} \mathrm{g}^{-1}\right)$ treatments. Similarly, the $\mathrm{P} 1000$ treatment also led to significantly higher root $\mathrm{P}$ concentration than that of the $\mathrm{P} 0$ or P35 treatment, for both the wild type (7.18 $\mathrm{mg} \mathrm{P} \mathrm{g}^{-1}$ ) and brb mutant (7.13 $\mathrm{mg} \mathrm{P} \mathrm{g}^{-1}$ ) (Table 2).

\subsection{Split-Root System}

The split-root system was divided into five treatments (TR1-5) as described in Table 1. Seedlings were imaged at 24 DAT before harvest for wild-type (Figure 2A) and mutant (Figure 2B). Since only the wild-type developed root hairs, whereas the mutant did not form any root hairs, only one photo was taken of the mutant root at 10 DAT as shown in Figure 2C. 
(A)
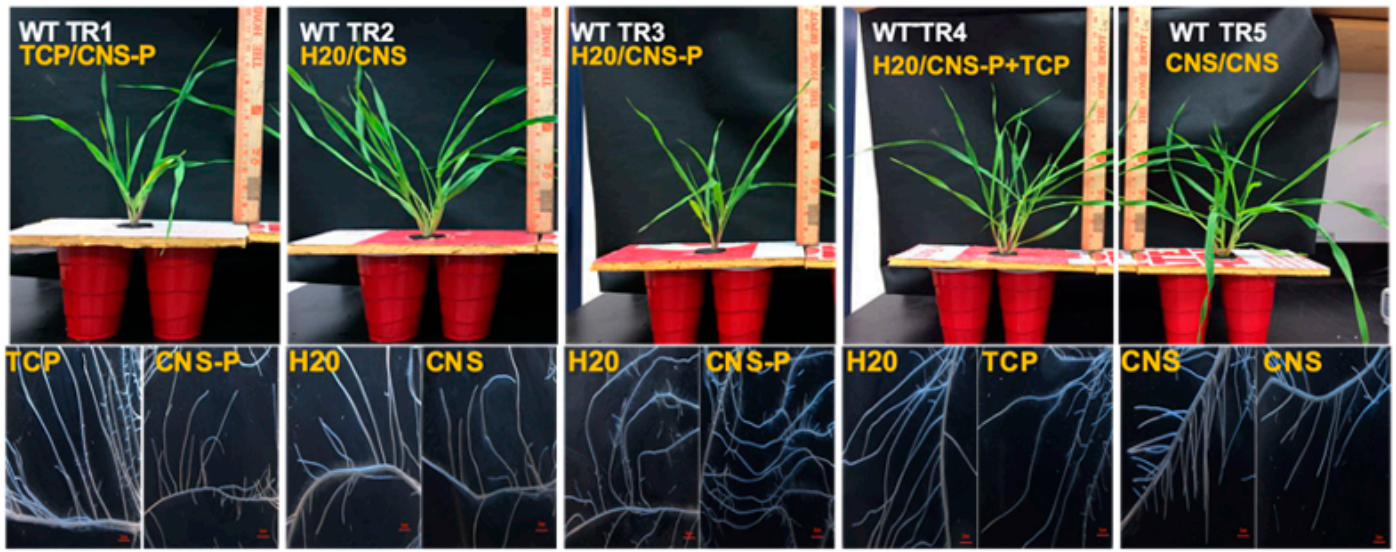

(B)
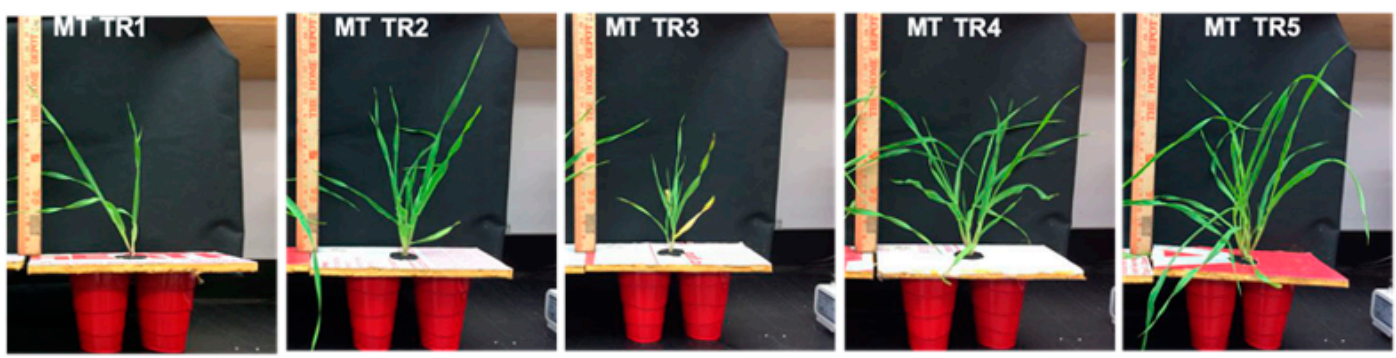

(C)

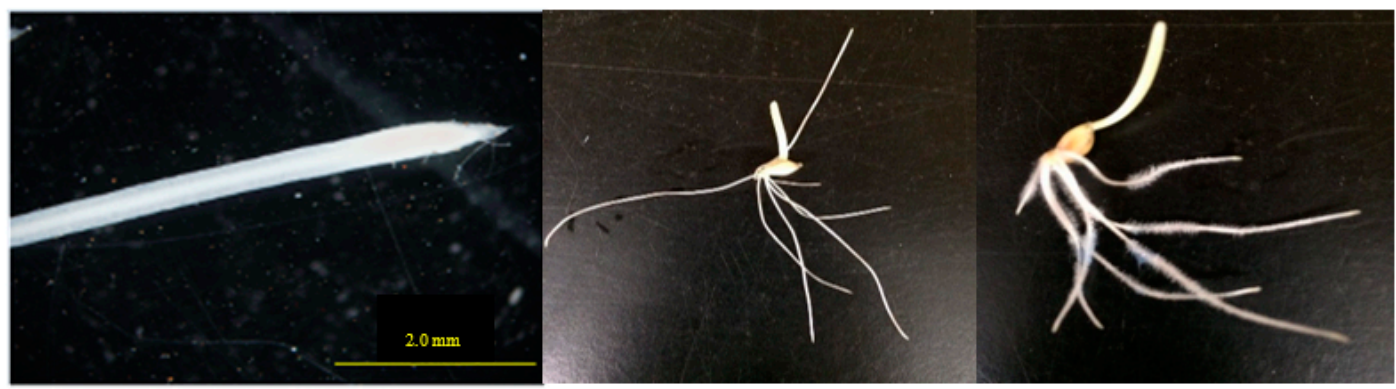

Figure 2. Images taken at 24 DAT of plant sizes and root of the five treatments of wide type (A) and seedling of the mutant (B) and mutant root (C) - left: taken at 24 DAT with a microscope camera, one single root with a $2.0 \mathrm{~mm}$ scale; middle: taken with a regular camera, a mutant seedling without any root hair; right: taken with a regular camera, a wide type seedling with prolific root hairs.

Solution $\mathrm{pH}$ decreased after 23 DAT when both genotypes were grown in the split-root system (Figure 3). Specifically, when complete nutrients (CNS) were supplied to one side of root, that half of cups have significantly lower $\mathrm{pH}(\mathrm{pH}<6.1)$ than others (Figure 3$)$. Interestingly, when TCP/CNS-P (TR1) was supplied to the wild type, this genotype with root hairs buffered the solution $\mathrm{pH}$ around 6.5, whereas the mutant without root hairs had a lower $\mathrm{pH}(\mathrm{pH}=6.2)$ at 23 DAT (Figure 3). 

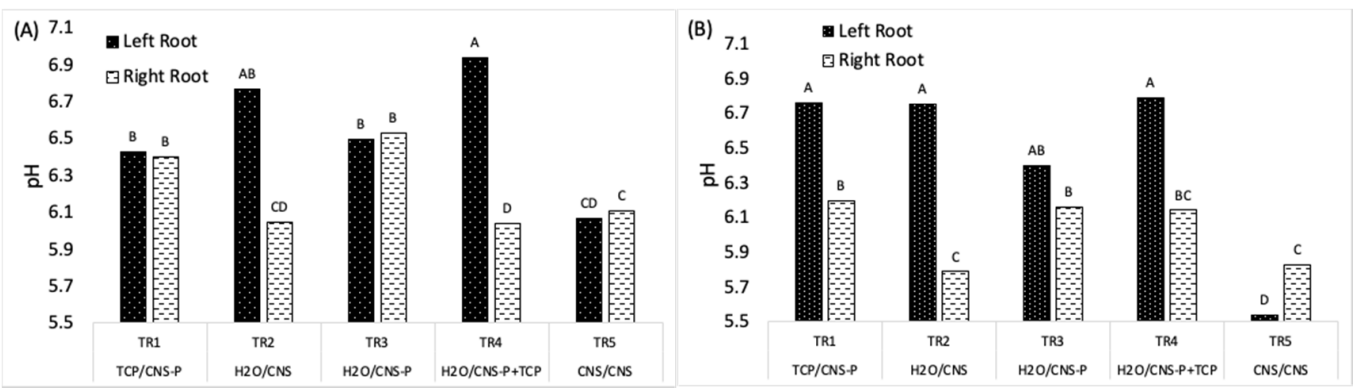

Figure 3. Differences in $\mathrm{pH}$ in the culture solutions of various split-root treatments on day 23. (A) wild-type barley (B) mutant brb barley. The initial $\mathrm{pH}$ was adjusted to 7.2. Different letters indicate significant difference $(p<0.05)$ among the P treatments.

For the wild type, root hair growth in TR1 was significantly greater than in all the other treatments, where the mean root hair length reached $1.36 \mathrm{~mm}$ compared to $0.80 \mathrm{~mm}$ in TR2 through TR4, and $0.25 \mathrm{~mm}$ in TR5. Root hair density was $68 \mathrm{~mm}^{-1}$ in TR1 compared to $48 \mathrm{~mm}^{-1}$ in TR2 through TR4, and $5 \mathrm{~mm}^{-1}$ in TR5 (control) (Figure 4).
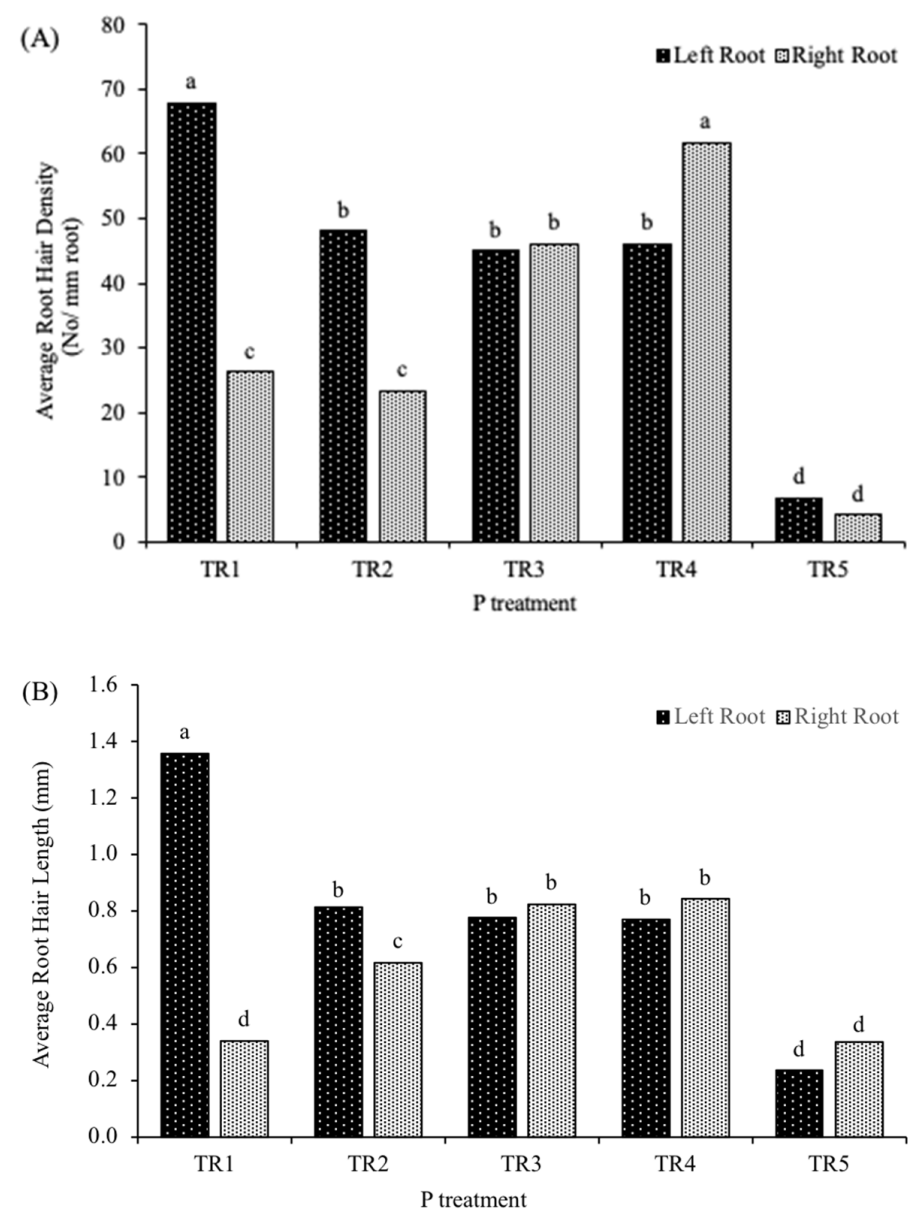

Figure 4. Measurement of root hairs of wild-type barley seedlings with different phosphorus (P) concentrations in the nutrient media in split-root treatments, (A) Average root hair density, (B) Average root hair length. For the measurements of root hair density and length, $N=10$. Measurements were made 10 days after transferring (DAT) plants to the measurement solution. Different letters indicate significant differences $(p \leq 0.05)$ among P levels of the wild-type seedlings according to a Tukey's HSD test. 
In the split-root system, the wild type (with data pooled for all treatments) had a P uptake rate of $1.0 \mu \mathrm{mol}$ plant ${ }^{-1} \mathrm{~h}^{-1}$, which was significantly greater than that of the $b r b\left(0.8 \mu \mathrm{mol}\right.$ plant $^{-1} \mathrm{~h}^{-1}$, Figure 5). Additionally, in the split-root system, there were differences in P depletion from the solution among the treatments within eight hours. There was no significant interaction between genotype and $\mathrm{P}$ treatment. When roots on either side of the split-root system were in a low-P solution buffered by TCP (TR1 and TR4), P uptake rates were significantly greater than those with no P supplied to either side of the split-root system (TR3). For the seedlings with both halves of the root system (TR5) or only one-half of the root system (TR2) in a complete nutrient solution, the P uptake rate was lower than that of those grown in a low-P solution (on either side of the root system) buffered by TCP (TR1 and TR4, Figure 5).

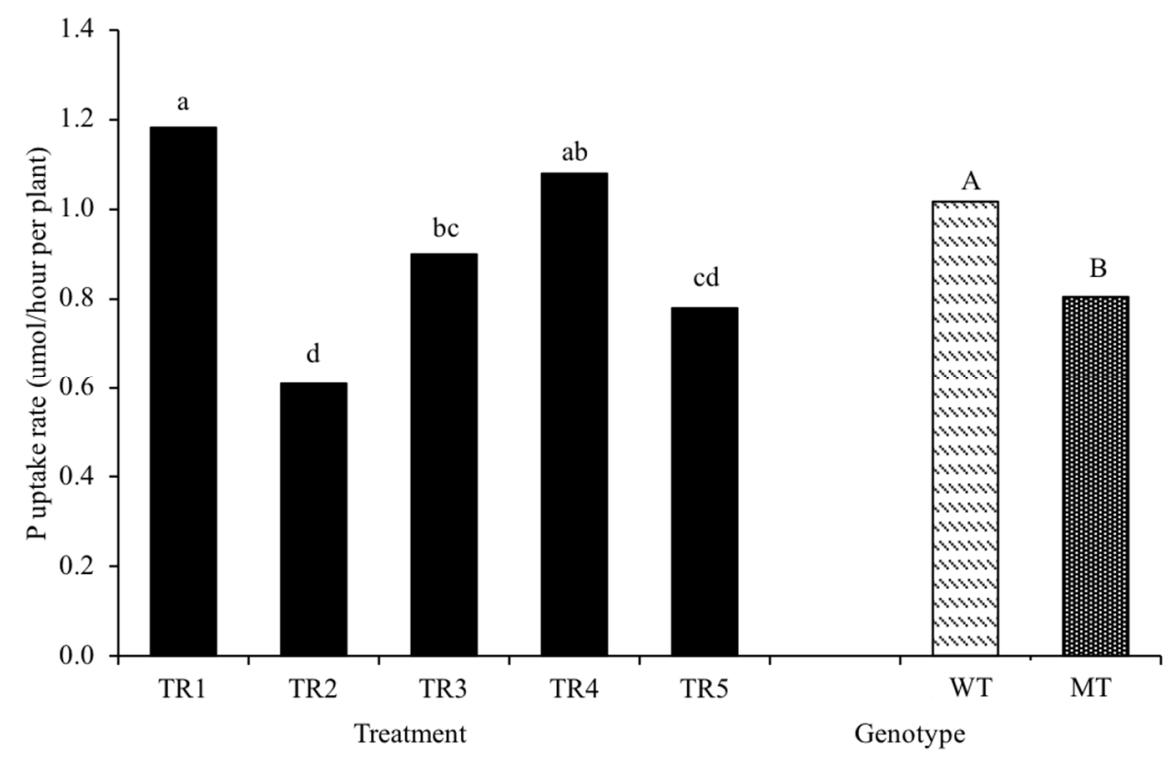

Figure 5. Phosphorus uptake rate of two barley genotypes in nutrient solutions with different $\mathrm{P}$ levels in a split-root system. The $\mathrm{P}$ treatments were: TR1 $=\mathrm{TCP} / \mathrm{CNS}-\mathrm{P}$, TR2 $=\mathrm{H}_{2} \mathrm{O} / \mathrm{CNS}$, TR3 $=\mathrm{H}_{2} \mathrm{O} / \mathrm{CNS}-\mathrm{P}$, TR4 $=\mathrm{H}_{2} \mathrm{O} / \mathrm{CNS}-\mathrm{P}+\mathrm{TCP}$, TR5 $=\mathrm{CNS} / \mathrm{CNS}$. The solution was sampled once every two hours for eight hours to determine the remaining $\mathrm{P}$ concentration $(\mathrm{N}=4)$. Different lower-case letters indicate significant differences $(p \leq 0.05)$ among treatments and different upper-case letters indicate significant difference $(p \leq 0.05)$ between the genotypes according to a Tukey's HSD test. WT stands for wild type, and MT for the root hairless brb mutant.

Shoot dry weight of the wild type $\left(1.6 \mathrm{~g} \mathrm{plant}^{-1}\right)$ was significantly greater than that of the $\mathrm{brb}$ mutant (1.3 g plant ${ }^{-1}$, Figure 6A). Considering the treatment effect in the split-root system, plants had fewer tillers and leaves and developed P-deficiency symptoms when low-P or no P was supplied. The seedlings had greater shoot dry weight when supplied with high soluble $\mathrm{P}$ or when TCP was mixed with other nutrients (TR2, TR4, and TR5) than TCP separated from other nutrients or no P was supplied (TR1 and TR3). Most importantly, when TCP was mixed with other nutrients in the same root compartment (TR4), the shoot dry weight was similar to that of the seedlings with high P supplied (TR2 and TR5). The seedlings supplied with sufficient $\mathrm{P}$ had greater shoot biomass production than those suffering from low P stress (Figure 6A). 
(A)
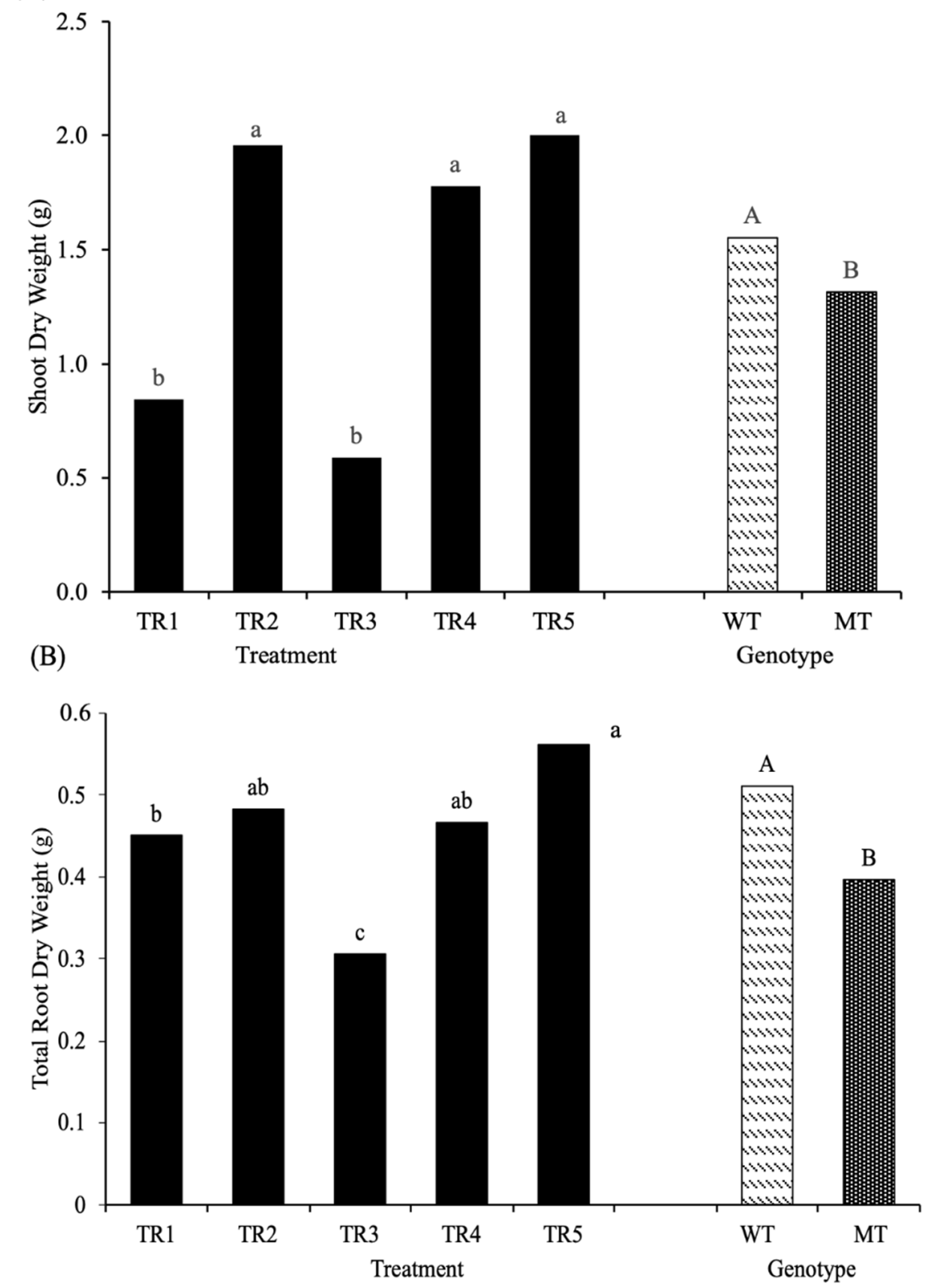

Figure 6. Shoot and total root dry biomass of two barley genotypes in a split-root system with the following P treatments: TR1-TCP/CNS-P; TR2- $\mathrm{H}_{2} \mathrm{O} / \mathrm{CNS}$; TR3- $\mathrm{H}_{2} \mathrm{O} / \mathrm{CNS}-\mathrm{P}$; TR4- $\mathrm{H}_{2} \mathrm{O} / \mathrm{CNS}-\mathrm{P}+\mathrm{TCP}$; TR5-CNS/CNS, (A) Shoot dry weight (B) Root dry weight, total root dry weight which was calculated by adding left and right root dry biomass together. Different lower-case letters indicate significant differences $(p \leq 0.05)$ among $P$ treatments and different upper-case letters indicate significant difference $(p \leq 0.05)$ between the genotypes according to a Tukey's HSD test. WT represents the wild type, and MT the root hairless mutant $b r b$.

Root dry weight of the wild-type (51 mg plant ${ }^{-1}$ ) was significantly greater than that of the brb mutant (40 mg plant ${ }^{-1}$, Figure 6B), suggesting a genotypic effect on root biomass production. However, there is interaction between genotype and treatment effects. For example, the biomass of root on the left side of the mutant under TR1 and TR2 are significantly higher than that of the wild type (Figure 7). As shoots accumulated greater dry weight in the high P treatments (TR2, $48 \mathrm{mg} \mathrm{plant}^{-1}$; TR4, $46 \mathrm{mg} \mathrm{plant}^{-1}$; and TR5, $56 \mathrm{mg} \mathrm{plant}^{-1}$ ), the corresponding root tissues also had significantly greater dry weight when external $\mathrm{P}$ was abundant. This was particularly pronounced in TR1; when 
P was buffered by TCP but separated from the other nutrients the shoot biomass was much lower $\left(0.8 \mathrm{~g} \mathrm{plant}^{-1}\right)$ than that of those in TR2 (2.0 $\left.\mathrm{g} \mathrm{plant}^{-1}\right)$, TR4 (1.8 $\left.\mathrm{g} \mathrm{plant}^{-1}\right)$, and TR5 $\left(2.0 \mathrm{~g} \mathrm{plant}^{-1}\right)$, whereas the root biomass ( $45 \mathrm{mg}$ plant $^{-1}$ ) was not significantly different from those in the high $\mathrm{P}$ treatments (Figure 6B).

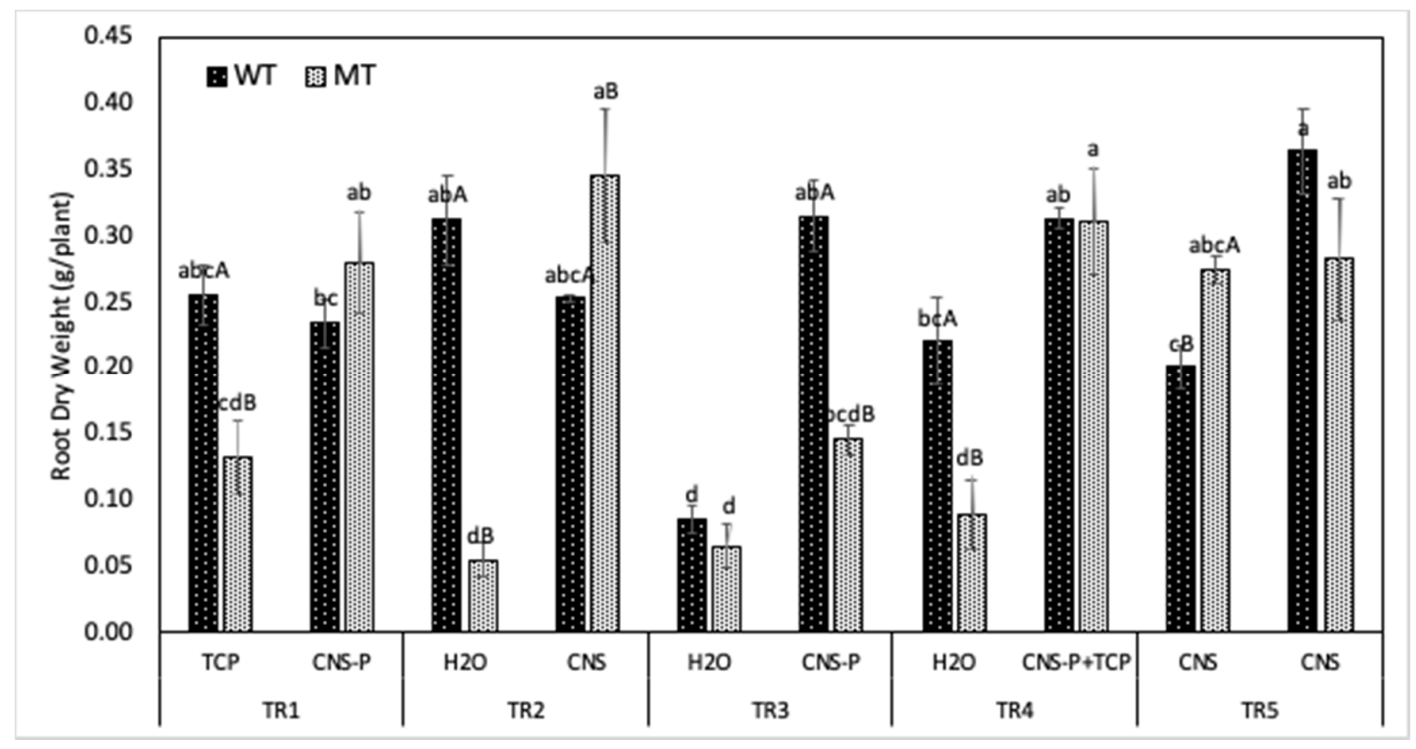

Figure 7. Root dry biomass of specific root section of two barley genotypes in a split-root system with the following $\mathrm{P}$ treatments: from left to right, the measurements followed the order: TR1-TCP/CNS-P; TR2- $\mathrm{H}_{2} \mathrm{O} / \mathrm{CNS}$; TR3- $\mathrm{H}_{2} \mathrm{O} / \mathrm{CNS}-\mathrm{P}$; TR4- $\mathrm{H}_{2} \mathrm{O} / \mathrm{CNS}-\mathrm{P}+\mathrm{TCP}$; TR5-CNS/CNS. The root biomass was demonstrated for left and right root sections, respectively. Different lower-case letters indicate significant differences $(p \leq 0.05)$ among the $\mathrm{P}$ treatments and different upper-case letters represent significant difference $(p \leq 0.05)$ between the genotypes according to a Tukey's HSD test. WT stands for root hair wild type, whereas MT means root hairless mutant.

There were significant interactions between genotype and $\mathrm{P}$ treatment for shoot and root $\mathrm{P}$ concentrations. Within either genotype, shoot $\mathrm{P}$ concentration was greater with high $\mathrm{P}$ in the nutrient solution (TR2, $\mathrm{H}_{2} \mathrm{O} / \mathrm{CNS}$ and TR5, CNS/CNS) than with low or no P supplied (TR1, TCP/CNS-P; TR3, $\mathrm{H}_{2} \mathrm{O} / \mathrm{CNS}-\mathrm{P}$, and TR4, $\left.\mathrm{H}_{2} \mathrm{O} / \mathrm{CNS}-\mathrm{P}+\mathrm{TCP}\right)$. The shoot $\mathrm{P}$ concentration of the wild type was greater in TR1, TR2, TR4, and TR5 than in TR3 where no $P$ was supplied. However, the shoot $P$ concentration of the $b r b$ mutant was lower in TR1 than in TR2, TR3, TR4, and TR5, respectively (Table 3). Similarly, in the root compartment with sufficient P (TR2 left, TR5 left, and TR5 right-CNS) the root P concentration of the wild type was about 4 to 5 -fold greater than that of the other treatments. In the right compartment of the split-root system, each of TR2, TR3, and TR4, which had the same content $\left(\mathrm{H}_{2} \mathrm{O}\right.$ only), the $\mathrm{P}$ concentration in plant tissue, was the greatest in TR2 $\left(2.11 \mathrm{mg} \mathrm{P} \mathrm{g}^{-1}\right)$, followed by TR4 $\left(1.53 \mathrm{mg} \mathrm{P} \mathrm{g}^{-1}\right)$ and TR3 (1.19 $\mathrm{mg} \mathrm{P} \mathrm{g}^{-1}$ ), which was correlated with the bioavailability of $\mathrm{P}$ in the corresponding left compartment (TR2-CNS, TR3-CNS-P, TR4-CNS-P + TCP), suggesting interference from the other compartment when using the split-root system. The root $\mathrm{P}$ concentration of the brb mutant was greater in CNS (TR2, TR5-left, and TR5-right) than in $\mathrm{H}_{2} \mathrm{O}$ (TR2, TR3, TR4-right) or CNS-P (TR1 and TR3-right) treatments. However, the lowest root $\mathrm{P}$ concentrations in plant tissue was in the TR4 (CNS-P + TCP, $0.47 \mathrm{mg} \mathrm{P} \mathrm{g}^{-1}$ ) treatment (Table 3). 
Table 3. Root and shoot $\mathrm{P}$ concentrations in two barley genotypes with selected $\mathrm{P}$ treatments in a split-root system.

\begin{tabular}{|c|c|c|c|c|c|}
\hline \multicolumn{4}{|c|}{ Treatment } & \multirow{2}{*}{\multicolumn{2}{|c|}{$\frac{\text { P Concentration (mg P/g Dry Weight) }}{\text { Shoot }}$}} \\
\hline & \multirow{2}{*}{ Cup Contents } & \multicolumn{2}{|c|}{ Root } & & \\
\hline & & Wild Type & Mutant & Wild Type & Mutant \\
\hline \multirow{2}{*}{$\mathrm{TR}^{\mathrm{z}}$} & $\mathrm{TCP}^{\mathrm{z}}$ & $1.54 b^{y}$ & $1.52 \mathrm{bcd}$ & \multirow{2}{*}{$1.27 \mathrm{bcA}$} & \multirow{2}{*}{$0.82 \mathrm{cB}$} \\
\hline & CNS-P & $1.28 \mathrm{~b}$ & $1.14 \mathrm{~cd}$ & & \\
\hline \multirow{2}{*}{ TR2 } & $\mathrm{H}_{2} \mathrm{O}$ & $2.11 \mathrm{~b}$ & $2.65 \mathrm{~b}$ & \multirow{2}{*}{$2.21 \mathrm{bB}$} & \multirow{2}{*}{$3.55 \mathrm{bA}$} \\
\hline & CNS & $4.54 \mathrm{aB}$ & $5.81 \mathrm{aA}$ & & \\
\hline \multirow{2}{*}{ TR3 } & $\mathrm{H}_{2} \mathrm{O}$ & $1.19 \mathrm{~b}$ & $1.89 \mathrm{bc}$ & \multirow{2}{*}{$0.38 \mathrm{cB}$} & \multirow{2}{*}{$1.09 \mathrm{cA}$} \\
\hline & CNS-P & $1.13 \mathrm{~b}$ & $1.16 \mathrm{~cd}$ & & \\
\hline \multirow{2}{*}{ TR4 } & $\mathrm{H}_{2} \mathrm{O}$ & $1.53 \mathrm{~b}$ & $1.48 \mathrm{~cd}$ & \multirow{2}{*}{$0.47 \mathrm{cB}$} & \multirow{2}{*}{$1.14 \mathrm{cA}$} \\
\hline & CNS-P + TCP & $1.80 \mathrm{bA}$ & $0.47 \mathrm{~dB}$ & & \\
\hline \multirow{7}{*}{ TR5 } & CNS & $5.63 \mathrm{aB}$ & $6.48 \mathrm{aA}$ & \multirow{3}{*}{$4.61 \mathrm{aB}$} & \multirow{3}{*}{$6.00 \mathrm{aA}$} \\
\hline & CNS & $5.50 \mathrm{a}$ & $6.12 \mathrm{a}$ & & \\
\hline & & & gnificance & & \\
\hline & Genotype & \multicolumn{2}{|c|}{ * Significance } & \multicolumn{2}{|c|}{ * } \\
\hline & Treatment & \multicolumn{2}{|c|}{ * } & \multicolumn{2}{|c|}{ * } \\
\hline & Genotype * & \multirow{2}{*}{\multicolumn{2}{|c|}{ * }} & \multirow{2}{*}{\multicolumn{2}{|c|}{ * }} \\
\hline & Treatment & & & & \\
\hline
\end{tabular}

${ }^{\mathrm{z}}$ TR1-TCP/CNS-P; TR2-H ${ }_{2} \mathrm{O} / \mathrm{CNS}$; TR3- $\mathrm{H}_{2} \mathrm{O} / \mathrm{CNS}-\mathrm{P}$; TR4- $\mathrm{H}_{2} \mathrm{O} / \mathrm{CNS}-\mathrm{P}+\mathrm{TCP}$; TR5-CNS/CNS. ${ }^{\mathrm{y}}$ Different lower-case letters indicate significant difference among various $\mathrm{P}$ levels and different upper-case letters mean statistical difference between the two genotypes $(p \leq 0.05)$ according to a Tukey's HSD test. * indicates significant $(p \leq 0.5)$ of main effects or interactions according to two-way analysis of variance (ANOVA).

\section{Discussion}

\subsection{Effect of P Bioavailability on Root Hair Length and Density}

Root hair length is highly regulated by external $\mathrm{P}$ bioavailability. Root hair initiation and elongation are both induced by low-P stress, and those morphological traits are controlled by genetic factors $[12,19,24]$. Previous studies have shown that root hair length of barley ('Pallas' and 'Optic') increased from $0.68 \pm 0.14 \mathrm{~mm}$ in soil with a high (e.g., $10 \mu \mathrm{M}$ ) $\mathrm{P}$ to $0.80 \pm 0.20 \mathrm{~mm}$ in soil with low (e.g., $3 \mu \mathrm{M}) \mathrm{P}[10,14]$. Similarly, in our study, root hair length of the wild type ('Pallas') significantly increased in conditions of P limitation (Table 2). Our results suggest that TCP induces longer root hairs $(1.36 \mathrm{~mm})$ than no or low P in the root zone (Figure 4). Importantly, TCP was applied in both TR1 and TR4 except for the co-occurrence of other nutrients (CNS-P) or not, and root hairs in TR1 were significantly longer than in TR4 (Figure 4). This can be attributed to the difference in the P bioavailability in TCP with and without other nutrients. When TCP is mixed with other nutrients (CNS-P) as in TR4, iron in the solution could interact with phosphorus to generate imbalanced iron uptake and $\mathrm{pH}$ change [25]. In addition to root hair length, root hair density was sensitive to P deficiency $[12,20]$. Another study comparing root hair growth with $\mathrm{P}$ and $\mathrm{Cd}$ uptake from soil reported that the root hair density in 'Pallas' was $78 \mathrm{~mm}^{-1}$ root and root hair length was $1.29 \mathrm{~mm}$ when no P was applied to the soil [26]. Our study confirms those findings that root hair density declined with increasing $\mathrm{P}$ bioavailability. Interestingly, the root hairless mutant used in our experiment is a spontaneous mutant from cv. 'Pallas' [15], confirmed by root anatomical observation with a light microscope showing that no root hairs or trichoblasts differentiated into root hairs regardless of external growth conditions [15].

\subsection{Function of Root Hairs on Phosphorus Uptake and Plant Growth}

Root hairs are indispensable during P-deficient conditions because they enhance plant $\mathrm{P}$ uptake and maintain plant growth, whereas they are unnecessary when external $P$ is sufficient [14]. However, a study of $\mathrm{P}$ uptake kinetics in Arabidopsis found that root hairs increased P uptake in a sand-alumina medium with low $\mathrm{P}$, whereas variation in root hair length or density did not affect $\mathrm{P}$ uptake and 
transport with either low-P or high-P in the nutrient solution [27]. This discrepancy may be attributed to differences in the $\mathrm{P}$ uptake media; the sand-alumina created a diffusion-limited low-P condition in the root zone, facilitating the extension of a depletion zone for P uptake [27]. In our study, TCP was used as the only $\mathrm{P}$ source. This $\mathrm{P}$ source released bioavailable $\mathrm{P}$ gradually as it was taken up by plants. Therefore, as compared to the traditional hydroponics, this system was P-buffered and able to reduce the depletion zone for $P$ acquisition by plants.

Similarly, the P uptake dynamics showed no genotypic difference when sufficient soluble $\mathrm{NaH}_{2} \mathrm{PO}_{4}$ $\left(16.14 \mu \mathrm{moL} \mathrm{plant}^{-1}\right)$ in the nutrient solution was provided, except for TR1 and TR4 in the split-root system (Figure 5). In those two root compartments, the wild type had a greater P uptake rate than the $b r b$ mutant. Our data were consistent with the hypothesis that root hairs are critical for P uptake when external $\mathrm{P}$ bioavailability is suboptimal, and TCP can keep providing bioavailable $\mathrm{P}$ and mimic soil solutions with low-P solutions. Another study indicated that when external P was low $(3 \mu \mathrm{M})$, the P-uptake rate was 2.1-fold greater in the wild-type 'Pallas' than in the brb mutant. In contrast, when $\mathrm{P}$ was high $(10 \mu \mathrm{M})$, the P-uptake rate was 1.7 -fold greater in the wild type than in the root hairless brb mutant [14]. Our results also demonstrated that the wild-type plants had a greater P uptake rate when exposed low $\mathrm{P}$ in the root zone compared to high $\mathrm{P}$ in the root zone $\mathrm{P}$ (Figure 5), which was closely correlated with the variation in root hair development.

Plant biomass and $\mathrm{P}$ accumulation in plant tissues are effective indicators for identifying P-efficient cultivars, representing ultimate economic yield and P acquisition efficiency [23,28]. In the present study, the wild-type barley had greater shoot and root biomass than the $b r b$ mutant, and an abundant external P supply significantly increased plant biomass compared to a P-deficient growth medium (Table 2 and Figure 6). Our results are different from a previous study showing that when grown in soil, biomass of the wild type and brb mutant did not differ significantly under well-watered conditions, but the $b r b$ mutant produced more root fresh weight than the wild type under dry soil conditions regardless of high or low soil P concentration [29]. Additionally, Li et al. [29] reported that the brb mutant had diminished root biomass, irrespective of soil moisture content. This discrepancy may be explained by the fact that in the soil, wild type plants can adjust to soil moisture conditions to maintain a relatively high $\mathrm{P}$ concentration in the shoot tissue, therefore maintaining normal shoot growth. Our study used TCP as the P source to establish a plant-controlled P release system [13]. When plants absorbed P or its counter cations, calcium ions, more $\mathrm{P}$ was released from TCP. The system kept a low-P signal and hence accelerated root hair growth and $\mathrm{P}$ uptake.

When TCP was applied in the hydroponic solution of the split-root system, the wild type demonstrated a greater $\mathrm{P}$ uptake rate and biomass production than sufficient soluble $\mathrm{P}$ conditions (Figures 5 and 6). These data indicated that this system simulated a soil condition and induced similar morphological responses that might be observed in a soil solution. Explanations for the morphological variation in root hair growth between soil and solution cultures include differences in soil moisture conditions [30,31] and sensitivity of root hairs to phosphorus availability [20]. The results of our study suggest that the split-root solution culture system can mimic a soil solution (Figure 1; Figure 4). Thus, it is useful for future root hair genetics studies by avoiding the damage to root systems, which usually occurs in soil or semi-solid root medium.

\subsection{Using a Split Root System with TCP to Simulate a Soil Solution}

Root hair length and density, and P uptake responses to the split-root system with low-P and a traditional (non-split-root) hydroponic system are summarized in Table 4. Although the split-root system with TCP in the culture solution induced prolific root hair formation and growth, and other physiological responses, as observed in soil with low $\mathrm{P}, \mathrm{P}$ absorbed by one-half of the root system was transferred to the other half of the split root system. This translocation event was supported by the data of TR2, the right compartment had CNS with $1000 \mu \mathrm{M}$ P, and the left compartment had only distilled water. TR2 had a greater P concentration than TR4 in the roots of the mutant. In other experiments utilizing a split-root system with an increased gradient of P fertilizer, high P supplied to one half of the 
roots significantly increased the P concentration in the corresponding other half [2]. Similarly, Liu et al. found the half of roots in the P-rich medium transferred $P$ to the other half of roots in distilled water only [13]. Their explanation for this phenomenon was that when half of the root system was in a P-sufficient condition, $\mathrm{P}$ was transferred internally to the other half of the root system deprived of $\mathrm{P}$ and caused the release of $\mathrm{P}$ into growth medium. Despite this transfer of $\mathrm{P}$, the side that was exposed to TCP produced the most root hairs, suggesting that root hair development was stimulated by low but steady bioavailability of $\mathrm{P}$ in the nutrient solution and calcium might have played a stimulating role in the process.

Table 4. Comparison of $\mathrm{P}$ uptake and plant growth between split-root system and non-split-root system in response to external $\mathrm{P}$ concentration in the nutrient solution.

\begin{tabular}{|c|c|c|}
\hline \multicolumn{2}{|c|}{ Split-Root System } & \multirow{2}{*}{\begin{tabular}{l}
\multicolumn{1}{c}{ Non-Split-Root System } \\
Root hair growth has been \\
decreased compared to when TCP \\
being used to simulate soil P \\
stressed condition
\end{tabular}} \\
\hline Root hair growth & $\begin{array}{l}\text { Increased root hair length and } \\
\text { density growth when tri-calcium } \\
\text { phosphate is used to mimic soil } \\
\text { condition }\end{array}$ & \\
\hline$P$ uptake rate & $\begin{array}{l}\text { The wild-type had greater } \mathrm{P} \\
\text { uptake rate than the root hairless } \\
\text { mutant }\end{array}$ & $\begin{array}{l}\text { No difference was detected } \\
\text { between the wild-type and the } \\
\text { mutant }\end{array}$ \\
\hline Biomass production & $\begin{array}{l}\text { The wild-type had greater shoot } \\
\text { and root biomass than the mutant }\end{array}$ & $\begin{array}{l}\text { The wild-type had greater shoot } \\
\text { and root biomass than the mutant }\end{array}$ \\
\hline \multirow[t]{2}{*}{ P concentration } & $\begin{array}{l}\text { The mutant had higher shoot } \mathrm{P} \\
\text { concentration than the wild-type } \\
\text { through TR2 to TR } 5 \\
\text { The wild-type had increased shoot } \\
\text { P concentration compared to the } \\
\text { mutant in P-buffered TR1 } \\
\text { condition }\end{array}$ & $\begin{array}{l}\text { The mutant maintained higher } \\
\text { shoot } \mathrm{P} \text { concentration than the } \\
\text { wild-type }\end{array}$ \\
\hline & $\begin{array}{l}\text { No genotypic difference between } \\
\text { wild-type and mutant in TR1 } \\
\text { treatment }\end{array}$ & $\begin{array}{l}\text { No genotypic difference in root } \mathrm{P} \\
\text { concentration was found }\end{array}$ \\
\hline Translocation & $\begin{array}{l}\text { An interaction existed between the } \\
\text { left and right cup compartments } \\
\text { since both side roots share the } \\
\text { same shoot tissue }\end{array}$ & $\begin{array}{l}\text { Both wild type and mutant plants } \\
\text { had more consistent responses for } \\
\text { biomass production and P } \\
\text { concentration, i.e., plants had } \\
\text { higher dry weight and P } \\
\text { concentration in high P compared } \\
\text { to low P or no P. }\end{array}$ \\
\hline $\mathrm{pH}$ difference & $\begin{array}{l}\text { When TCP is supplied to one half } \\
\text { of the cup, and other nutrients are } \\
\text { added to the other half of the cup, } \\
\text { pH in the TCP side can be buffered }\end{array}$ & $\begin{array}{l}\text { When TCP is supplied together } \\
\text { with other nutrients in one } \\
\text { container, pH can decrease two to } \\
\text { three units as plants take up more } \\
\text { cationic ions than anionic ions }\end{array}$ \\
\hline $\begin{array}{l}\text { P bioavailability of the } \\
\text { TCP in the solution }\end{array}$ & $\begin{array}{l}\text { P bioavailability of the TCP can be } \\
\text { kept at a low level continuously } \\
\text { when TCP was supplied } \\
\text { separately from other nutrients for } \\
\text { plant growth }\end{array}$ & $\begin{array}{l}\mathrm{P} \text { bioavailability of the TCP would } \\
\text { increase as the } \mathrm{pH} \text { drops caused } \\
\text { by plant taking up more cations }\end{array}$ \\
\hline
\end{tabular}

\section{Conclusions}

This study investigated the role of root hairs on P uptake and plant growth with different P bioavailability levels by using two barley genotypes: a wild type, 'Pallas', with root hairs and its hairless mutant $b r b$. The wild type had a greater number of root hairs and longer root hairs when grown in a P-limited solution than in a solution with adequate $P$. The greatest $\mathrm{P}$ uptake rate was 
observed for the plants grown in a culture solution with TCP, which was separated from the other nutrients in a split-root system. The comparison between the wild type and the $b r b$ mutant indicated that there was no genotypic difference in the P uptake rate and root $\mathrm{P}$ concentration when they were both grown in a traditional hydroponic solution. This result indicated that the wild type formed root hairs in either low or relatively high P supply, but the root hairs did not make significant contribution to $P$ uptake. However, when utilizing a split-root system, the wild-type plants had greater P uptake than the $b r b$ mutant. Root hairs were effective for enhancing P uptake when the seedlings were exposed to $P$ deficient conditions. This study demonstrated that using a split-root system with TCP stimulated root hair growth and increased $\mathrm{P}$ uptake of barley seedlings grown in a buffered low-P solution. This buffered low-P technique is effective and convenient for studying root hair traits. The technique makes it easier to observe and quantify root morphology without interference from soil contaminants.

Author Contributions: This is part of the M.S. thesis of Y.X., G.L. and Y.X. conceptualized the experiments. Y.X. conducted the experiments, analyzed the data, and drafted the manuscript. Writing - review \& editing, B.R., B.S. and R.M. All authors subsequently contributed to editing and improving the final manuscript. All authors have read and agreed to the published version of the manuscript.

Funding: Germplasm Project funded by Dean for Research of UF/IDAS.

Acknowledgments: We thank T.S. Gahoonia at the Plant Nutrition and Soil Fertility Laboratory, Department of Agricultural Sciences, Royal Veterinary and Agricultural University, Copenhagen, Denmark, for the mutant barley plants. This graduate research program was financially supported by the Horticultural Sciences Department at The University of Florida/IFAS. We thank Christine Chase for help with the greenhouse. We also thank Anna-Lisa Paul for providing the microscope for root hair imaging and Lisa David, Agata Zupanska, and Jordan Callaham for assistance with root hair measurements. We appreciate Edward Hanlon, at the University of Florida for reviewing and improving the manuscript.

Conflicts of Interest: The authors declare no competing interests.

\section{References}

1. Guppy, C.N.; Menzies, N.W.; Moody, P.W.; Blamey, F.P.C. Competitive sorption reactions between phosphorus and organic matter in soil: A review. Soil Res. 2005, 43, 189-202. [CrossRef]

2. Shabnam, R.; Iqbal, M.T. Understanding phosphorus dynamics on wheat plant under split-root system in alkaline soil. Braz. J. Sci. Technol. 2016, 3, 19. [CrossRef]

3. Holford, I.C.R. Soil phosphorus: Its measurement, and its uptake by plants. Soil Res. 1997, 35, $227-240$. [CrossRef]

4. Bieleski, R.L. Phosphate pools, phosphate transport, and phosphate availability. Annu. Rev. Plant Physiol. 1973, 24, 225-252. [CrossRef]

5. Raghothama, K.G. Phosphate acquisition. Annu. Rev. Plant. Physiol. Plant Mol. Biol. 1999, 50, 665-693. [CrossRef] [PubMed]

6. Gourley, C.J.P.; Allan, D.L.; Russelle, M.P. Defining phosphorus efficiency in plants. Plant Soil 1993, 155, 289-292. [CrossRef]

7. Hammond, J.; Broadley, M.; White, P.; King, G.; Bowen, H.; Hayden, R.; Meacham, M.; Mead, A.; Overs, T.; Spracklen, W.; et al. Shoot yield drives phosphorus use efficiency in Brassica oleracea and correlates with root architecture traits. J. Exp. Bot. 2009, 60, 1953-1968. [CrossRef]

8. Wang, X.; Shen, J.; Liao, H. Acquisition or utilization, which is more critical for enhancing phosphorus efficiency in modern crops? Plant Sci. 2010, 179, 302-306. [CrossRef]

9. Parentoni, S.N.; Souza Júnior, C.L. De Phosphorus acquisition and internal utilization efficiency in tropical maize genotypes. Pesqui. Agropecuária Bras. 2008, 43, 893-901. [CrossRef]

10. Brown, L.K.; George, T.S.; Thompson, J.A.; Wright, G.; Lyon, J.; Dupuy, L.; Hubbard, S.F.; White, P.J. What are the implications of variation in root hair length on tolerance to phosphorus deficiency in combination with water stress in barley (Hordeum vulgare)? Ann. Bot. 2012, 110, 319-328. [CrossRef]

11. Raghothama, K.G. Phosphorus and plant nutrition: An overview. Phosphorus Agric. Environ. 2005, 353-378.

12. Brown, L.K.; George, T.S.; Dupuy, L.X.; White, P.J. A conceptual model of root hair ideotypes for future agricultural environments: What combination of traits should be targeted to cope with limited P availability? Ann. Bot. 2013, 112, 317-330. [CrossRef] [PubMed] 
13. Liu, G.D.; Dunlop, J.; Phung, T.; Li, Y. Physiological responses of wheat phosphorus-efficient and -inefficient genotypes in field and effects of mixing other nutrients on mobilization of insoluble phosphates in hydroponics. Commun. Soil Sci. Plant. Anal. 2007, 38, 2239-2256. [CrossRef]

14. Gahoonia, T.S.; Nielsen, N.E. Phosphorus (P) uptake and growth of a root hairless barley mutant (bald root barley, $b r b$ ) and wild type in low- and high-P soils. Plant Cell Environ. 2003, 26, 1759-1766. [CrossRef]

15. Gahoonia, T.S.; Nielsen, N.E.; Joshi, P.A.; Jahoor, A. A root hairless barley mutant for elucidating genetic of root hairs and phosphorus uptake. Plant Soil 2001, 235, 211-219. [CrossRef]

16. Genc, Y.; Huang, C.Y.; Langridge, P. A study of the role of root morphological traits in growth of barley in zinc-deficient soil. J. Exp. Bot. 2007, 58, 2775-2784. [CrossRef]

17. Kwasniewski, M.; Szarejko, I. Molecular cloning and characterization of $\beta$-expansin gene related to root hair formation in barley. Plant Physiol. 2006, 141, 1149-1158. [CrossRef]

18. Gahoonia, T.S.; Nielsen, N.E. Variation in root hairs of barley cultivars doubled soil phosphorus uptake. Euphytica 1997, 98, 177-182. [CrossRef]

19. Bates, T.R.; Lynch, J.P. Stimulation of root hair elongation in Arabidopsis thaliana by low phosphorus availability. Plant. Cell Environ. 1996, 19, 529-538. [CrossRef]

20. Ma, Z.; Bielenberg, D.G.; Brown, K.M.; Lynch, J.P. Regulation of root hair density by phosphorus availability in Arabidopsis thaliana. Plant. Cell Environ. 2001, 24, 459-467. [CrossRef]

21. Akhtar, M.S.; Oki, Y.; Nishigaki, M.; Adachi, T.; Nakashima, Y.; Nakamoto, Y.; Hartwig, C. Phosphorus stress induced variations in growth behavior and P efficiency among Brassica cultivars grown with sparingly soluble P sources. Commun. Soil Sci. Plant Anal. 2014, 45. [CrossRef]

22. Liu, G.D.; Gu, B.; Miao, S.L.; Li, Y.C.; Migliaccio, K.W.; Qian, Y. Phosphorus release from ash and remaining tissues of two wetland species after a prescribed fire. J. Environ. Qual. 2010, 39, 1585-1593. [CrossRef] [PubMed]

23. Huang, C.Y.; Shirley, N.; Genc, Y.; Shi, B.; Langridge, P. Phosphate utilization efficiency correlates with expression of low-affinity phosphate transporters and noncoding RNA, IPS1, in Barley. Plant Physiol. 2011, 156, 1217-1229. [CrossRef] [PubMed]

24. Schiefelbein, J.; Ford, S.; Galway, M.; Kinkema, M.; Masucci, J.; Ilkbahar, Y.; Begin, C. Genetic and Molecular Analysis of Root Cell-Development. In Journal of Cellular Biochemistry; John Wiley \& Sons Inc.: New York, NY, USA, 1993; p. 7.

25. Liu, G.D.; James, D.; Thai, P.; Zhao, Q. Induction of root hair growth in a phosphorus-buffered culture solution. Agric. Sci. China 2006, 5, 370-376. [CrossRef]

26. Zheng, R.; Li, H.; Jiang, R.; Römheld, V.; Zhang, F.; Zhao, F.-J. The role of root hairs in cadmium acquisition by barley. Environ. Pollut. 2011, 159, 408-415. [CrossRef] [PubMed]

27. Bates, T.R.; Lynch, J.P. The efficiency of Arabidopsis thaliana (Brassicaceae) root hairs in phosphorus acquisition. Am. J. Bot. 2000, 87, 964-970. [CrossRef]

28. Akhtar, M.; Oki, Y.; Nakashima, Y.; Adachi, T.; Nishigaki, M. Phosphorus stress-induced differential growth, and phosphorus acquisition and use efficiency by spring wheat cultivars. Commun. Soil Sci. Plant Anal. 2016, 47. [CrossRef]

29. Dodd, I.C.; Diatloff, E. Enhanced root growth of the brb (bald root barley) mutant in drying soil allows similar shoot physiological responses to soil water deficit as wild-type plants. Funct. Plant Biol. 2016, 43, 199-206. [CrossRef]

30. Li, T.; Lin, G.; Zhang, X.; Chen, Y.; Zhang, S.; Chen, B. Relative importance of an arbuscular mycorrhizal fungus (Rhizophagus intraradices) and root hairs in plant drought tolerance. Mycorrhiza 2014, 24, 595-602. [CrossRef]

31. Mackay, A.D.; Barber, S.A. Effect of soil moisture and phosphate level on root hair growth of corn roots. Plant Soil 1985, 86, 321-331. [CrossRef]

(C) 2020 by the authors. Licensee MDPI, Basel, Switzerland. This article is an open access article distributed under the terms and conditions of the Creative Commons Attribution (CC BY) license (http://creativecommons.org/licenses/by/4.0/). 